\title{
Scales for Coping Strategy Perception and an Implementation Scheme of "Tuition-Free Enrollment for Vocational High School Students"
}

\author{
Hui-Yi Pai, Tsai-Ku Liao, Chin-Wen Liao, and Chin-Chang Wu
}

\begin{abstract}
His research aims to develop scales for coping strategy perception and the implementation scheme of "Tuition-free Enrollment for Vocational High School Students". To make sure that the scales have rigorous constructive reliability and validity, the trial test questionnaires are analyzed by statistical software for factor analysis, item analysis and Cronbach's $\alpha$ to determine the questionnaire's reliability and validity; the data will be used as reference for selecting questions in the formal questionnaire. The questionnaire includes 33 questions to measure six dimensions: "strategic alliance", "exquisite teaching", "feature management", "professional development", "innovative teaching" and "resources deployment".
\end{abstract}

Index Terms-Tuition-free enrollment for vocational high school students, perception, coping strategy.

\section{BACKGROUND AND OBJECTIVES}

\section{A. Background}

Education is of vital and lasting importance. Since the implementation of nine-year mandatory education for citizens in 1968, Taiwan has experienced many changes in educational reforms and related degrees. Making education more accessible to the general public not only helps our country to cultivate elites in various fields, but also sustains Taiwan's economic miracle.

However, the "knowledge economy" of the 21st century has precluded the nine-year mandatory education from meeting the demands of society. Children need to possess more abilities, including the ability to solve questions, the ability to successfully handle communication and negotiations, creative abilities, the ability to cope with conflicts, high EQ, and so on. The Ministry of Education (MOE) initiated many reform plans to meet these demands [1]. As early as 1983, Taiwan proposed the concept of "elongating the period of education for citizens, with an emphasis on vocational education." This concept was continuously changed or adjusted until 2011, when the President announced, in his New Year's Day proclamation that the "12-year fundamental education" for citizens was to be launched and gradually implemented in several phases.

To lower the financial burden for economically disadvantaged families concerning education, it was

Manuscript received March 8, 2014; revised May 15, 2014.

The authors are with the Department of Industrial Education and Technology at National Changhua University of Education (NCUE), Taiwan (e-mail: yi2323222@yahoo.com.tw, tsaikuliao@gmail.com, tcwliao@cc.ncue.edu.tw,wcc1102@yahoo.com.tw). announced that vocational education started to pilot "tuition-free enrollment for Vocational High School students". It is estimated that in 2014 tuition fees will be waved in all Vocational High Schools, and entrance exams omitted in a majority of schools, in order to make Taiwan a country with "evenly distributed wealth and justice" [2]. In addition, on Sep. 20, 2011, the Executive Yuan certified the "plans for implementing 12-year fundamental education for citizens" (Taiwan Educational No. 1000103358), which will be implemented in 2014 [3].

Difficulties facing the implementation of "tuition-free enrollment for Vocational High School students" may involve financial or legal problems. For example, believes that a healthy financial structure needs to be built [4]. As citizens' income continues to increase, the government should strengthen financial subsidies and assistance for upper secondary education holds that the educational funding for the prolonged education of citizens can proceed by raising funds from grassroots or corporations [5], by increasing taxes from corporations or for-profit organizations, through government-issued educational bonds, by educational banks established by the government, or through annual savings with a fixed rate. Both scholars emphasize that the financial and legal resources should be legalized to ensure a complete and sustainable system. Another problem concerns the principle of fairness. As Li, Shin-Shing expressed [6], when it comes to the fairness of tuition-waving in Vocational High Schools, recipients of subsidies should exclude families that possess three or more three real estate properties, families whose real estate value is more than 6,500,000 NTD in total, families with an annual interest of 100,000 or more, or students who have received public educational subsidies or reduced tuition. In this regard, tuition-free enrollment for vocational high students would not overlap with related tuition subsides that are currently available, thereby, conforming to the principle of fairness in the distribution of resources.

Waving tuition for Vocational High School students causes quite a lot of confusion and conflict. As a result, this research will propose some coping strategies and implementation schemes concerning this topic. Moreover, this research will define coping strategies via researching scales. We expect that these scales will be used as reference for relevant competent authorities that care about this topic.

\section{B. The Research Purpose}

This research aims to develop coping strategy for tuition-free enrollment for Vocational High School students, as well as scales for the implementation scheme. Based on the 
research background stated above, the research has the following objectives:

1) Discussing the current conditions for the coping strategies and implementation scheme for scales concerning tuition-free enrollment for Vocational High School students.

2) Analyzing the scale content of the coping strategies and implementation scheme concerning tuition-free enrollment for Vocational High School students.

3) Developing the scales of the coping strategies and implementation scheme concerning tuition-free enrollment for Vocational High School students.

\section{RESEARCH DESIGN AND IMPLEMENTATION}

This research is a survey research. To achieve the purpose of this research, we first collected related data by conducting a literature review, then sorted out, modified and compiled a "Questionnaire on the Perception of Coping Strategies and Implementation Scheme of Tuition-Free Enrollment for Vocational High School Students", to serve as the research tool used in this research, based on the layout for this research.

In accordance with the purpose of the research, the coping strategy perception and the perception regarding tuition-free enrollment for Vocational High School students are discussed; the problem is exacerbated by Taiwan's low birth rate. The questionnaire in this research uses a Likert five-point scale; 5 points signifies "agree very much"; 4 points, "agree"; 3 points, "no comment"; 2 points, "disagree"; and 1 point, "disagree very much".

This research concerns the Vocational High School teachers' thoughts, observations and feelings about the tuition-free enrollment for Vocational High School students. This research contains three dimensions: supporting measures, target and content. The higher the research subjects score in the perception section on the questionnaire complied by the researchers, the better the research subjects comprehend the content of this scheme.

The procedures of compiling this questionnaire are described as follows:

\section{A. Steps of Research}

To effectively achieve its purpose, this research established systematic steps and has proceeded accordingly, as follows:

1) Propose a research direction and purpose: After conducting a literature review, determine that the theme of the research is Vocational High School teachers' coping strategies and perception of tuition-free enrollment for their students.

2) Collect and discuss the literature: collect and read related materials and research reports, synthesize and analyze the literature for establishing the theoretical foundation of this research.

3) Establish the research structure: This research determines the relationship between the independent variables and dependent variables, so as to establish the research structure according to the literature review.

4) Design a draft for the questionnaire: This research uses the questionnaire as a tool. After collecting the literature on the purpose of research, propose and then decide on a draft for the trial test questionnaire.

5) Peer review and modifications: Send the draft of the trial test questionnaire to experts in related fields for reviewing the trial test questions. Modify the questions based on the experts' opinions. After the questionnaire draft is compiled, establish the content validity of the questionnaire and modify the inappropriate questions.

6) Conduct the trial test with the trial test questionnaire and modifications:

Conduct the trial test with the trial test questionnaire among Vocational High School teachers in central Taiwan. Conduct factor analysis and item analysis on the responses, to modify and finalize the questionnaire.

\section{B. Research Structure}

In accordance with a literature review on related foreign and domestic literature, this research determines the related factors concerning Vocational High School teachers' coping strategy perception of tuition-free enrollment for their students, sorts out the relationship among the variables, and establishes the research structure to achieve the research purpose. The research involves two parts: dependent variables (including a tuition-free enrollment scheme and coping strategy perception) and independent variables (including school environment and teacher background). The related variables are described as follows:

\section{1) Dependent variables}

1) Variables concerning teachers' personal background: including gender, age, subjects, length of service, position, education, and so on;

2) Variables concerning school background: including school district and school affiliation.

\section{2) Independent variables}

1) Teachers' perception can be classified as:

- Supporting measures

- Content

- Target

2) Teachers' coping strategies can be classified as:

- Strategic alliance

- Exquisite teaching

- Feature management

- Professional development

- Resources deployment

\section{Research Subjects}

The main research subjects for this study are the full-time vocational teachers in public or private Vocational High Schools in Taiwan in 2011. A trial test was carried out after the experts had reviewed the validity of the questionnaire. The trial test questionnaires were issued from Apr. 1, 2012. The trial test subjects were selected from 4 Vocational High Schools, following the principle of purposive sampling, and 158 copies of trial test questionnaires were issued for the trial test, with the response rate about $98.75 \%$.

\section{Research Instruments}

This research is a survey research. To achieve the purpose of the research, the related literature is first collected, and 
then the materials are sorted out and modified in accordance with the research structure, to compile "Questionnaire on the Coping Strategy Perception and Implementation Schemes for Tuition-free Enrollment for Vocational High School Students", as the research tool. The procedures of compiling a questionnaire are described as follows:

\section{1) Determining the structure of the questionnaire and compiling a draft}

In order to objectively analyze Vocational High School teachers' perception of a tuition-free enrollment scheme for Vocational High School students and coping strategy, this research discusses the theoretical foundation of this study by conducting a literature review, and develops a draft of the questionnaire, showed as Table I. The questionnaire contains three parts: the first part contains basic information of the respondents, including teachers' personal background variables (gender, subject, age, education, length of service, position), as well as two variables about school environment (including school district and school affiliation); the second part is the questionnaire about teachers' perception of a tuition-free enrollment scheme, including three dimensions: supporting measures, target and content; the third part is the Questionnaire on Teachers' Perception of Coping Strategy of Tuition-Free Enrollment; it includes six dimensions: "strategic alliances", "exquisite teaching", "feature management", "professional development", "innovative teaching" and "resources deployment".

TABLE I: DIMENSIONS OF TEACHERS' PERCEPTION OF TUITION-FREE ENROLLMENT SCHEME AND COPING STRATEGY

\begin{tabular}{|c|c|c|c|}
\hline $\begin{array}{l}\text { Dependent } \\
\text { Variables }\end{array}$ & Dimensions & $\begin{array}{l}\text { Number of } \\
\text { Questions }\end{array}$ & Total \\
\hline \multirow{3}{*}{$\begin{array}{l}\text { Teachers' } \\
\text { Perception of } \\
\text { Tuition-free } \\
\text { Enrollment Scheme }\end{array}$} & Supporting measures & 4 & \multirow{3}{*}{21} \\
\hline & Content & 6 & \\
\hline & Target & 11 & \\
\hline \multirow{7}{*}{$\begin{array}{l}\text { Teachers' Coping } \\
\text { Strategy Perception } \\
\text { of Tuition-free } \\
\text { Enrollment }\end{array}$} & Strategic alliance & 6 & \multirow{6}{*}{33} \\
\hline & Exquisite teaching & 5 & \\
\hline & Feature management & 5 & \\
\hline & Professional development & 6 & \\
\hline & Innovative teaching & 5 & \\
\hline & Resources deployment & 6 & \\
\hline & Total & & 54 \\
\hline
\end{tabular}

\section{RESUlt ANALYSIS AND DisCUSSION}

\section{A. Establishing Content Validity}

When the draft of the questionnaire is completed, five professionals are invited to fill out Vocational High School Teachers' Perception of Tuition-free Enrollment Scheme and Teachers' Coping Strategy Perception of Tuition-free Enrollment - in Proceeding (Expert Review). The experts provide revision comments regarding the appropriateness and wording of the questions establish the content validity of the research instrument and use the content validity as an important reference for constructing the formal questionnaire. The experts and scholars examine the applicability one question after another. They check out one of these items under each question: usable, usable after modification, comments on modification, and delete. They also write out their modification comments in blanks, in order to establish the content validity of the research instrument and to use it as a reference for constructing the formal questionnaire.

\section{B. Conducting the Trial Test and Analyzing the Results}

In order to understand the applicability and usability of the questionnaire, the trial test questionnaires were gradually issued from Apr. 1, 2012, when the draft was completed. The trial test subjects were selected from 4 Vocational High Schools, following the principle of purposive sampling. One hundred and fifty-eight copies of the trial test questionnaires were issued and the trial test was conducted. The response rate was about $98.75 \%$.

In order to establish more rigorous construct validity and reliability for the research instrument, statistical software was used to conduct factor analysis, item analysis and Cronbach's $\alpha$ on the responses when trial test questionnaires were collected. The reliability and validity of the questionnaires thus established are used as reference for selecting questions when constructing the formal questionnaire. The explanations are as follows:

\section{1) Item analysis}

In accordance with the criteria for deleting a question, the questionnaire on Vocational High School Teachers' Perception of Tuition-Free Enrollment for Their Students, which was used in this research, contains a total of 21 questions, covering three dimensions: supporting measures, target and content, respectively. Results of the statistical analysis using SPSS are displayed in Table II; question 12 has a cumulative $\alpha$ smaller than .4 , with a significance level higher than .05 , indicating that question 12 should be deleted for its lack of homogeneity with the overall scale, while the rest of questions should be kept.

TABLE II: ITEM ANALYSIS OF THE QUESTIONNAIRE ON VOCATIONAL HIGH SCHOOL TEACHERS' PERCEPTION OF TUITION-FREE ENROLLMENT FOR THEIR STUDENTS

\begin{tabular}{llll}
\hline \hline \multirow{2}{*}{ Question } & CR value & $\begin{array}{l}\text { Pearson's Correlation } \\
\text { Coefficients between } \\
\text { Question and Scale Total }\end{array}$ & $\begin{array}{l}\text { Cronbach's } \alpha \\
\text { after the } \\
\text { question is }\end{array} \quad$ Remark
\end{tabular}

\begin{tabular}{|c|c|c|c|c|}
\hline & Score & & & \\
\hline 1 & 4.640 & $.414(* *)$ & .912 & Kept \\
\hline 2 & 6.657 & $.528(* *)$ & .910 & Kept \\
\hline 3 & 6.855 & $.582(* *)$ & .909 & Kept \\
\hline 4 & 9.135 & $.652(* *)$ & .907 & Kept \\
\hline 5 & 8.628 & $.619(* *)$ & .908 & Kept \\
\hline 6 & 7.864 & $.643(* *)$ & .907 & Kept \\
\hline 7 & 9.733 & $.701(* *)$ & .906 & Kept \\
\hline 8 & 7.446 & $.634(* *)$ & .907 & Kept \\
\hline 9 & 7.270 & $.578(* *)$ & .909 & Kept \\
\hline 10 & 8.426 & $.639(* *)$ & .907 & Kept \\
\hline 11 & 8.364 & $.612(* *)$ & .908 & Kept \\
\hline 12 & 3.849 & $.350(* *)$ & .914 & Deleted \\
\hline 13 & 8.061 & $.477(* *)$ & .911 & Kept \\
\hline 14 & 7.941 & $.520(* *)$ & .911 & Kept \\
\hline 15 & 11.809 & $.702(* *)$ & .905 & Kept \\
\hline 16 & 11.060 & $.710(* *)$ & .905 & Kept \\
\hline 17 & 9.767 & $.694(* *)$ & .906 & Kept \\
\hline 18 & 1.088 & $.745(* *)$ & .904 & Kept \\
\hline 19 & 9.017 & $.621(* *)$ & .908 & Kept \\
\hline 20 & 9.244 & $.655(* *)$ & .907 & Kept \\
\hline 21 & 6.106 & $.583(* *)$ & .908 & Kept \\
\hline
\end{tabular}

The value of Cronbach's $\alpha$ (Internal consistency) is .912 for the overall scale before deleting that question.

Note: $N=158$; * means significant correlation at $p<.01$ (two-tailed).

In accordance with the criteria for deleting a question, the questionnaire on Vocational High School Teachers' 
Perception of Tuition-free Enrollment for Their Students, which was used in this research, contains 33 questions, covering six dimensions: "strategic alliance", "exquisite teaching", "feature management", "professional development", "innovative teaching" and "resources deployment", respectively. Results of the statistical analysis using SPSS are displayed in Table III; in accordance with the criteria for deleting a question, questions 29 and 32 have cumulative $\alpha$ that are smaller than .4 , with a significance level higher than .05 , indicating that both questions should be deleted for their lack of homogeneity with the overall scale, while the rest of questions should all be kept.

TABLE III: ITEM ANALYSIS ON THE QUESTIONNAIRE ON VOCATIONAL HIGH SCHOOL TEACHERS' PERCEPTION OF TUITION-FrEE ENROLLMENT FOR

\begin{tabular}{|c|c|c|c|c|}
\hline Question & $\begin{array}{c}\text { CR } \\
\text { value }\end{array}$ & $\begin{array}{c}\text { Pearson's Correlation } \\
\text { Coefficients between } \\
\text { Question and Scale Total } \\
\text { Score }\end{array}$ & $\begin{array}{l}\text { Cronbach's } \\
\alpha \text { after the } \\
\text { question is } \\
\text { deleted }\end{array}$ & Remark \\
\hline 22 & 8.313 & $.632(* *)$ & .929 & Kept \\
\hline 23 & 6.126 & $.609(* *)$ & .929 & Kept \\
\hline 24 & 7.806 & $.686(* *)$ & .928 & Kept \\
\hline 25 & 6.685 & $.554(* *)$ & .930 & Kept \\
\hline 26 & 9.100 & $.715(* *)$ & .928 & Kept \\
\hline 27 & 7.193 & $.644(* *)$ & .929 & Kept \\
\hline 28 & 6.047 & $.553(* *)$ & .930 & Kept \\
\hline 29 & 4.115 & $.384(* *)$ & .933 & Deleted \\
\hline 30 & 4.450 & $.455(* *)$ & .932 & Kept \\
\hline 31 & 4.389 & $.440(* *)$ & .932 & Kept \\
\hline 32 & 2.613 & $.309(* *)$ & .934 & Deleted \\
\hline 33 & 8.759 & $.619(* *)$ & .929 & Kept \\
\hline 34 & 9.277 & $.619(* *)$ & .929 & Kept \\
\hline 35 & 7.298 & $.541(* *)$ & .930 & Kept \\
\hline 36 & 1.110 & $.612(* *)$ & .929 & Kept \\
\hline 37 & 7.851 & $.625(* *)$ & .929 & Kept \\
\hline 38 & 9.513 & $.633(* *)$ & .929 & Kept \\
\hline 39 & 7.963 & $.619(* *)$ & .929 & Kept \\
\hline 40 & 7.732 & $.601(* *)$ & .929 & Kept \\
\hline 41 & 6.667 & $.565(* *)$ & .930 & Kept \\
\hline
\end{tabular}

\begin{tabular}{ccccc}
\hline 42 & 4.939 & $.492(* *)$ & .931 & Kept \\
\hline 43 & 7.632 & $.558(* *)$ & .930 & Kept \\
\hline 44 & 7.379 & $.553(* *)$ & .930 & Kept \\
\hline 45 & 8.603 & $.664(* *)$ & .929 & Kept \\
\hline 46 & 7.256 & $.564(* *)$ & .930 & Kept \\
\hline 47 & 9.564 & $.664(* *)$ & .928 & Kept \\
\hline 48 & 9.001 & $.651(* *)$ & .929 & Kept \\
\hline 49 & 8.598 & $.661(* *)$ & .929 & Kept \\
\hline 50 & 8.443 & $.665(* *)$ & .929 & Kept \\
\hline 51 & 6.511 & $.579(* *)$ & .929 & Kept \\
\hline 52 & 6.766 & $.606(* *)$ & .929 & Kept \\
\hline 53 & 6.395 & $.562(* *)$ & .930 & Kept \\
\hline 54 & 9.257 & $.671(* *)$ & .929 & Kept \\
\hline \hline
\end{tabular}

The value of Cronbach's $\alpha$ (Internal consistency) is .932 for the overall scale before deleting that question, Note: $N=158$;

$*$ means significant correlation at $=.01$ (two-tailed).

\section{2) Factor analysis}

In the results of the first analysis, X2 value in Bartlett's Test of Sphericity is $1597.450, \mathrm{KMO}=.875(d f=190), \rho<.05$, indicating that common factors exist in the relation matrix in the sample, and that it is appropriate to use factor analysis on the responses to this questionnaire. Three factors are extracted with characteristic values of 5.590, 3.062 and 2.696, respectively. The bigger a characteristic value, the more important that factor is in explaining variable constructs. These three factors account for $27.952 \%, 15.308 \%$ and $13.482 \%$ of the variance, respectively. The three factors cumulatively explain $56.742 \%$ of the variance, as displayed in Table IV and Table V.

TABLE IV: KMO AND BARTLETT'S TEST

\begin{tabular}{llr}
\hline $\begin{array}{l}\text { Kaiser-Meyer-Olkin } \\
\text { Measure of Sampling } \\
\text { Adequacy }\end{array}$ & & .875 \\
\hline Bartlett's Test of Sphericity & Approx. Chi-Square & 1597.450 \\
\hline & df & 190 \\
\hline & Sig. & .000 \\
\hline
\end{tabular}

TABLE V: FACTOR ANALYSIS ON TEACHERS' PERCEPTION OF TUITION-FrEE ENROLLMENT

\begin{tabular}{|c|c|c|c|c|}
\hline $\begin{array}{l}\text { Question \# in the trial } \\
\text { test questionnaire }\end{array}$ & Factor 1 & Factor 2 & Factor 3 & $\begin{array}{l}\text { Question \# in } \\
\text { the formal } \\
\text { questionnaire }\end{array}$ \\
\hline 17 & .755 & .239 & -.021 & 1 \\
\hline 15 & .734 & .213 & .076 & 2 \\
\hline 18 & .731 & .339 & .044 & 3 \\
\hline 9 & .730 & .030 & -.034 & 4 \\
\hline 6 & .683 & .229 & -.011 & 5 \\
\hline 7 & .683 & .211 & .171 & 6 \\
\hline 16 & .674 & .201 & .239 & 7 \\
\hline 4 & .667 & .064 & .277 & 8 \\
\hline 8 & .640 & .022 & .322 & 9 \\
\hline 5 & .606 & -.103 & .530 & 10 \\
\hline 10 & .511 & .299 & .234 & 11 \\
\hline 13 & -.003 & .726 & .294 & 12 \\
\hline 20 & .436 & .652 & .023 & 13 \\
\hline 21 & .283 & .592 & .219 & 14 \\
\hline 14 & .317 & .564 & -.060 & 15 \\
\hline 19 & .476 & .553 & -.032 & 16 \\
\hline 11 & -.082 & .525 & .345 & 17 \\
\hline 2 & .132 & .205 & .840 & 18 \\
\hline 1 & .092 & .053 & .816 & 19 \\
\hline 3 & .179 & .364 & .687 & 20 \\
\hline Characteristic value & 5.590 & 3.062 & 2.696 & \\
\hline$\%$ of variance explained & $27.952 \%$ & $15.308 \%$ & $13.482 \%$ & \\
\hline Cumulative $\%$ of variance explained & $39.002 \%$ & $49.261 \%$ & $56.742 \%$ & \\
\hline
\end{tabular}

After factor analysis, some questions are kept, as displayed in Table VI. 
TABLE VI: QUESTIONS KEPT AFTER FACTOR ANALYSIS ON THE SCALE OF TUITION-FREE ENROLLMENT SCHEME

\begin{tabular}{cllc}
\hline Factor & Factor Name & $\begin{array}{l}\text { Question \# in the } \\
\text { trial test } \\
\text { questionnaire }\end{array}$ & $\begin{array}{l}\text { Number of } \\
\text { questions }\end{array}$ \\
\hline 1 & $\begin{array}{l}\text { Supporting } \\
\text { measures }\end{array}$ & $2,1,3$ & 3 \\
\hline 2 & Content & $\begin{array}{l}13,20,21,14,19, \\
11\end{array}$ & 6 \\
\hline 3 & Target & $\begin{array}{l}17,15,18,9,6,7, \\
16,4,8,5,10\end{array}$ & 11 \\
\hline
\end{tabular}

In the results of the first analysis of Coping Strategy in the trial test questionnaire, $\chi^{2}$ value in Bartlett's Test of Sphericity is $3345.483, \mathrm{KMO}=.886(d f=465), \rho<.05$, indicating that common factors exist in the relation matrix in the sample, and that it is appropriate to use factor analysis on the responses to this questionnaire. Six factors are extracted from factor analysis on Coping Strategy, and factor No. 6 includes questions 31 and 30 , and includes fewer than 3 questions; therefore, questions 31 and 30 are deleted before the second Coping Strategy factor analysis is conducted. When factors No. 5 and 6 are combined, the characteristic values are 5.381, 4.392, 4.287, 3.094, 2.335 and 1.835, respectively. The bigger a characteristic value is, the more important that factor is in explaining variable constructs. These six factors account for $17.359 \%, 14.166 \%, 13.829 \%$, $9.979 \%, 7.532 \%$ and $5.920 \%$ of the variance, respectively. Six factors cumulatively explain $68.785 \%$ of the variance, as displayed in Table VII, Table VIII, TABLE IX and TABLEX.

TABLE VII: KMO AND BARTLETT'S TEST FOR THE QUESTIONNAIRE ON VOCATIONAL High SCHOOL TEACHERS' COPING STRATEGy PERCEPTION OF

Kaiser-Meyer-Olkin TUITION-FREE ENROLLMENT

Measure of Sampling

892

Adequacy

\begin{tabular}{crr}
\hline Bartlett's Test of Sphericity & Approx. Chi-Square & 3173.658 \\
\hline df & 406 \\
\hline Sig. & .000 \\
\hline
\end{tabular}

TABLE VIII: SECOND FACTOR ANALYSIS ON VOCATIONAL HIGH SCHOOL TEACHERS' COPING STRATEGY PERCEPTION OF TUITION-FREE ENROLLMENT

\begin{tabular}{|c|c|c|c|c|c|c|c|}
\hline (A) & $\begin{array}{l}\text { Factor } \\
1\end{array}$ & $\begin{array}{l}\text { Factor } \\
2\end{array}$ & $\begin{array}{l}\text { Factor } \\
3\end{array}$ & $\begin{array}{l}\text { Factor } \\
4\end{array}$ & $\begin{array}{l}\text { Factor } \\
5\end{array}$ & $\begin{array}{l}\text { Factor } \\
6\end{array}$ & (B) \\
\hline 50 & .781 & .232 & .131 & .015 & .153 & .130 & 21 \\
\hline 51 & .762 & .055 & .229 & .098 & -.058 & .124 & 22 \\
\hline 54 & .752 & .148 & .135 & .192 & .193 & .112 & 23 \\
\hline 49 & .734 & .161 & .205 & .158 & .178 & .017 & 24 \\
\hline 52 & .681 & .063 & .155 & .258 & .152 & .018 & 25 \\
\hline 47 & .681 & .174 & .077 & .433 & .137 & -.032 & 26 \\
\hline 48 & .669 & .167 & .093 & .386 & .235 & -.102 & 27 \\
\hline 53 & .609 & .162 & .131 & -.003 & .282 & .071 & 28 \\
\hline 45 & .566 & .162 & .141 & .408 & .370 & -.085 & 29 \\
\hline 23 & .106 & .838 & .148 & .068 & .079 & .116 & 30 \\
\hline 24 & .156 & .812 & .272 & .071 & .159 & .095 & 31 \\
\hline 22 & .183 & .796 & .154 & .103 & .135 & -.024 & 32 \\
\hline 27 & .196 & .665 & .268 & .147 & .022 & .193 & 33 \\
\hline 25 & .217 & .658 & .385 & -.247 & .056 & .076 & 34 \\
\hline 26 & .225 & .624 & .399 & .174 & .058 & .179 & 35 \\
\hline 28 & .044 & .536 & .147 & .331 & .042 & .190 & 36 \\
\hline 34 & .220 & .197 & .806 & .146 & -.012 & .053 & 37 \\
\hline 36 & .249 & .173 & .805 & -.023 & .206 & .022 & 38 \\
\hline 37 & .123 & .256 & .773 & .130 & .179 & .046 & 39 \\
\hline
\end{tabular}

(A)Question \# in the trial test questionnaire; (B) Question \# in the formal questionnaire
TABLE IX: SECOND FACTOR ANALYSIS ON VOCATIONAL HigH SCHOOL TEACHERS' COPING STRATEGY PERCEPTION OF TUITION-FREE ENROLLMENT

\begin{tabular}{|c|c|c|c|c|c|c|c|}
\hline (A) & $\begin{array}{l}\text { Factor } \\
1\end{array}$ & $\begin{array}{l}\text { Factor } \\
2\end{array}$ & $\begin{array}{l}\text { Factor } \\
3\end{array}$ & $\begin{array}{l}\text { Factor } \\
4\end{array}$ & $\begin{array}{l}\text { Factor } \\
5\end{array}$ & $\begin{array}{l}\text { Factor } \\
6 \\
\end{array}$ & (B) \\
\hline 33 & .204 & .237 & .717 & .052 & .039 & .239 & 40 \\
\hline 35 & .093 & .268 & .710 & .042 & .200 & -.061 & 41 \\
\hline 38 & .129 & .298 & .608 & .193 & .320 & .028 & 42 \\
\hline 44 & .270 & .060 & .054 & .800 & .002 & .178 & 43 \\
\hline 43 & .217 & -.003 & .250 & .717 & .165 & .089 & 44 \\
\hline 42 & .170 & .126 & -.022 & .688 & .265 & .093 & 45 \\
\hline 46 & .305 & .340 & .109 & .615 & -.003 & -.265 & 46 \\
\hline 39 & .383 & .125 & .243 & .120 & .787 & .009 & 47 \\
\hline 42 & .341 & .147 & .243 & .147 & .712 & .009 & 48 \\
\hline 41 & .313 & .108 & .255 & .252 & .649 & -.108 & 49 \\
\hline 31 & .065 & .239 & .103 & .006 & -.011 & .849 & $\begin{array}{c}\text { Delet } \\
\text { ed }\end{array}$ \\
\hline 30 & .116 & .186 & .077 & .158 & -.043 & .845 & $\begin{array}{c}\text { Delet } \\
\text { ed }\end{array}$ \\
\hline (C) & 5.381 & 4.392 & 4.287 & 3.094 & 2.335 & 1.835 & \\
\hline (D) & $\begin{array}{r}17.35 \\
9 \% \\
\end{array}$ & $\begin{array}{r}14.16 \\
6 \% \\
\end{array}$ & $\begin{array}{r}13.82 \\
9 \% \\
\end{array}$ & $\begin{array}{r}9.979 \\
\% \\
\end{array}$ & $\begin{array}{r}7.532 \\
\%\end{array}$ & $\begin{array}{r}5.920 \\
\% \\
\end{array}$ & \\
\hline (E) & $\begin{array}{r}17.35 \\
9 \%\end{array}$ & $\begin{array}{r}31.52 \\
5 \%\end{array}$ & $\begin{array}{r}45.35 \\
4 \%\end{array}$ & $\begin{array}{r}55.333 \\
\%\end{array}$ & $\begin{array}{r}62.86 \\
5 \%\end{array}$ & $\begin{array}{r}68.785 \\
\%\end{array}$ & \\
\hline
\end{tabular}

(A)Question \# in the trial test questionnaire

(B) Question \# in the formal questionnaire

(C)Characteristic value

(D) $\%$ of variance explained

(E)Cumulative \% of variance explained

TABLE X: QUESTIONS KEPT AFTER FACTOR ANALYSIS ON COPING STRATEGY SCALE

\begin{tabular}{cllc}
\hline Factor & Factor Name & $\begin{array}{l}\text { Question \# in the trial } \\
\text { test questionnaire }\end{array}$ & $\begin{array}{l}\text { Number of } \\
\text { questions }\end{array}$ \\
\hline 1 & Strategic alliance & $\begin{array}{l}50,51,54,49,52,53, \\
47,48,45\end{array}$ & 9 \\
\hline 2 & Exquisite teaching & $39,40,41$ & 3 \\
\hline 3 & Feature management & $34,36,37,33,35,38$ & 6 \\
\hline 4 & $\begin{array}{l}\text { Professional } \\
\text { development }\end{array}$ & $44,43,42,46$ & 4 \\
\hline 5 & Resources deployment & $\begin{array}{l}23,24,22,27,25,26, \\
28\end{array}$ & 7 \\
\hline
\end{tabular}

\section{3) Reliability analysis}

The value of the overall scale for the "perception" in this research is .914 . The values for internal consistency in three subscales are $.905, .751$ and .823 , respectively, as displayed in Table XI. The values for the overall scale and subscales are all above .70. The values confirm scholars' opinions. Therefore, it can be inferred that the internal consistency among the overall scale and its subscales is pretty good after certain questions are deleted.

TABLE XI: RELIABILITY ANALYSIS OF QUESTIONNAIRE ON VOCATIONAL HIGH SCHOOL TEACHERS' PERCEPTION OF TUITION-FREE ENROLLMENT

\begin{tabular}{|c|c|c|c|c|}
\hline \multicolumn{5}{|c|}{ SCHEME } \\
\hline $\begin{array}{l}\text { Factor } \\
\text { number }\end{array}$ & Factor name & Question \# & $\begin{array}{l}\text { Cronbach's } \\
\alpha \text { of each } \\
\text { factor }\end{array}$ & $\begin{array}{l}\text { Cronbach's } \\
\alpha \text { of the } \\
\text { overall scale }\end{array}$ \\
\hline 1 & $\begin{array}{l}\text { Supporting } \\
\text { measures }\end{array}$ & 11 & .823 & \multirow{3}{*}{.914} \\
\hline 2 & Content & 6 & .751 & \\
\hline 3 & Target & 3 & .905 & \\
\hline
\end{tabular}

The value of the overall scale for the "coping strategy" in this research is .942 . The values for internal consistency in five subscales are .918, .894, .901, .802 and .852, respectively, as displayed in Table XII . The values for the overall scale and subscales are all above .70. The values 
confirm scholars' opinions. Therefore, it can be inferred that the internal consistency among the overall scale and its subscales is pretty good after certain questions are deleted.

TABLE XII: RELIABILITY ANALYSIS OF QUESTIONNAIRE ON VOCATIONAL High SCHOOL TEACHERS' COPING STRATEGY PERCEPTION OF TUITION-FREE ENROLLMENT FOR THEIR STUDENTS

\begin{tabular}{lllll}
\hline $\begin{array}{l}\text { Factor } \\
\text { Number }\end{array}$ & Factor Name & $\begin{array}{l}\text { Number of } \\
\text { questions }\end{array}$ & $\begin{array}{l}\text { value for } \\
\text { each factor }\end{array}$ & $\begin{array}{l}\text { value for } \\
\text { the overall } \\
\text { scale }\end{array}$ \\
\hline Factor 1 & $\begin{array}{l}\text { Strategic } \\
\text { alliance }\end{array}$ & 9 & .918 & \\
\hline Factor 2 & $\begin{array}{l}\text { Exquisite } \\
\text { teaching }\end{array}$ & 7 & .852 & \\
\hline Factor 3 & $\begin{array}{l}\text { Feature } \\
\text { management }\end{array}$ & 6 & .901 & \\
\hline Factor 4 & $\begin{array}{l}\text { Professional } \\
\text { development }\end{array}$ & 4 & .802 & \\
\hline Factor 5 & $\begin{array}{l}\text { Resources } \\
\text { deployment }\end{array}$ & 3 & .894 & \\
\hline
\end{tabular}

\section{Completing the Formal Questionnaire}

Professionals and scholars provide revision comments on the trial test questionnaire used in this research; we then modify it based on factor analysis, item analysis and reliability analysis, delete questions that are not appropriate, rearrange question numbers, and compile the formal questionnaire. The questionnaire contains three parts: basic information about tuition waving and about the teacher who fills out the questionnaire, as well as a section on teachers' coping strategy perception of the tuition waving.

\section{CONCLUSION}

According to its purpose, this research examines the scale used, and the results of analysis are as follows:

1) Analyze the content of Coping Strategy Perception and Implementation scheme of "Tuition-free Enrollment for Vocational High School Students"

- Teachers' perception of tuition-free enrollment: Perception refers to a person's understanding of things, and does not include his or her emotions. Put simply, the perception is based on what facts are observed by a person, what thoughts that person develops concerning those facts, and the emotions that person has. Perception in this research refers to Vocational High School teachers' observations, thoughts and emotions about tuition-free enrollment for their students. This research includes three dimensions: supporting measures, target and content. Our researchers compile a questionnaire on these dimensions, and use numbers to evaluate the degree of perception. The higher a respondent scores on the perception section, the higher the teacher's level of perception of tuition-free enrollment.

- Vocational High School Teachers' Coping Strategy of Tuition-free Enrollment: Coping strategy is the reaction a person has when facing stress. Everyone feels differently about stress, and adopts different ways of coping with stress. When an individual is troubled, he or she has to adopt appropriate coping strategies to relieve stress. This research measures Vocational High School teachers' level of perception of tuition-free enrollment for their students.

2) Developing scales on the perception of coping strategy and implementation scheme of "tuition-free enrollment for Vocational High School students"

The formal questionnaire contains two parts: the first part includes independent variables (including variables about teacher background, school environment); the second part includes dependent variables (including scheme and coping strategy perception). The teachers' perception of scheme can be classified into: 1) Supporting measures; 2) Content; 3) Target.

Teachers' perception of Coping Strategies can be classified into: 1) strategic alliance; 2) exquisite teaching; 3) feature management; 4) professional development; 5) resources deployment

The scales above, according to reviews from experts and scholars, have achieved professional levels of content validity; in terms of the reliability test, the value for the overall scale about "perception" is .914, and the values for internal consistency of three subscales are $.905, .751$ and .823 , respectively; the value for the overall scale is .942 , and the values for internal consistency of five subscales are $.918, .894, .901, .802$ and .852 , respectively, as displayed in Table xii.

The values of the overall scale and subscales are all above .70 , and the reliability confirms the opinions of scholars'. Therefore, it can be inferred that the internal consistency for the overall scale and its subscales is pretty good after some questions are deleted.

\section{REFERENCES}

[1] Global Views Monthly Promoting 12-year Fundamental, 2007 Education-Make Children Enjoy Fairness, Happiness and Freedom.

[2] MOE. (September 25, 2011). Scheme on Tuition-free Enrollment for Vocational High School Students (excerpted edition). [Online]. Available:

http://www.tpde.edu.tw/ap/news_view.aspx?sn=02ebaac0-a01d-4139af30-65a801df2582.2011a

[3] MOE. Ministry of Education's Information Web Site about 12-year Fundamental Education. [Online]. Available: http://14.111.34.179/.2011b

[4] J. C. Han, "Exploring 12-year Fundamental Education," Administrators Research Association, R.O.C. 2006, vol. 44, pp. 85-97.

[5] F. Q. Zhang, "Disputes and reality about prolonged fundamental education," Taiwan Education Review, vol. 645, pp. 2-13. 2007.

[6] S. S. Li, "Examine the equalized tuition plan for both public and private high schools from the perspective of household income distribution," School Administrators Research Association, 2011, vol. 72, pp. 174-189.

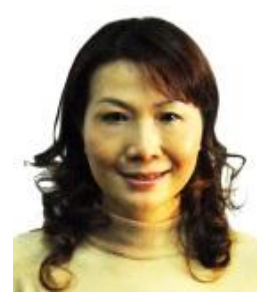

Hui-Yi Pai is dedicating her life in fine arts. She is pursuing her Ph.D. in Natioanl Changhua University of Education. She has had eight solo exhibitions all over the world including the recent one in Vancouver, Canada and a publication: Flash Back. Ms. Pai is the recipient of several awards such as French Art Salon collection award, International Japan FIA Art Exibition award, Taiwan Art Exhibition collection award, YuShan Art Exhibition collection award, Tai-Yang Art Exhibition award, Da Dung Fine Arts Exhibition award, Central Taiwan Art Exhibition award and Tea Township Thousand people outdoor sketching 


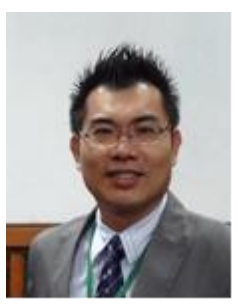

Tsai-Ku Liao received M.S. degree at the Department of Geography from National Taiwan Normal University in 2006, and currently is a doctoral student of the Department of Industrial Education and Technology at National Changhua University of Education (NCUE), Taiwan, R.O.C. Since August 2008 , he has been a director of Student Affairs and Library in National Taichung First Senior High School (TCFSH) in Taiwan, R.O.C. Since August 1998, he has taught courses in Geogrpahy, GIS , Monographic study in the same school.

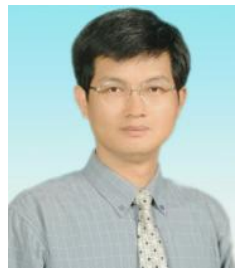

Chin-Wen Liao received his M.S. and Ph.D. in industrial education from National Taiwan Normal University, Taiwan, R.O.C. in 1994 and 2002, respectively. Since August 2011, he has been a professor in Department of Industrial Education and Technology at National Changhua University of Education (NCUE) in Taiwan, R.O.C. He teaches courses in technology and vocational education,

energy education, course and teaching, organizational learning. His research interests include technology and vocational education, teacher education, energy education of technology, and learning organization.

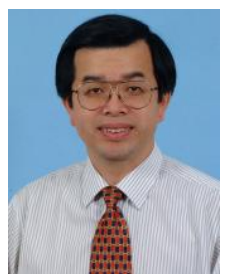

education.

Chin-Chang Wu received M.S. in education from National Changhua University of Education, Taiwan, R.O.C. and $\mathrm{Ph} . \mathrm{D}$ in industrial education and technology from National Changhua University of Education in 2005. He has been a school principal in Dong-Shing Elementary School, Taiwan, R.O.C. and dealt with administrative affairs of the school. His research interests include leading, technology, and vocational 